\title{
KONRAD ADENAUER DAN PEMODENAN SEMULA JERMAN BARAT, 1949-1963
}

\author{
Salmiahwati Djafar \\ Wan Shawaluddin Wan Hassan
}

\begin{abstract}
The Second World War had brought destruction to Germany as a political entity. More significantly the Germans lost everything including their sovereignty. The emergence of Konrad Adenauer in 1949 as the first Chancellor of West Germany(1949-1963), reinforced under the authority of the Allies, particularly the United States had opened the path towards modernization and the revival of West Germany after the division of Germany into two entities. Thus, this paper discusses the role of Adenauer in the revival of Germany and his contribution that led him to be regarded as the father of modern Germany. Among Adenauer's contribution are firstly, strengthening democracy as a new ideology of post-war West German society through the implementation of Basic Law; secondly, formulating domestic policy by strengthening West German economy through Marshall Plan and the introduction of the Market Economy to achieve what was to be said as the economic miracle. Further, status-quo during the Cold War era had enabled West Germany to be associated with European economic and military cooperation through ECSC, EEC and NATO that reflected the recognition for the sovereignty and integrity of Germany from the West as one of the powers of Western Europe.
\end{abstract}

\section{Pengenalan}

Lazimnya, kejatuhan dan kebangkitan sesebuah negara dipengaruhi oleh peranan yang dimainkan oleh pemimpinnya. Hal ini terbukti apabila tindakan yang diambil oleh Adolf Hitler telah membawa 
kepada keruntuhan negara Jerman selepas mengalami kekalahan dalam Perang Dunia Kedua. Namun, kejatuhan Jerman tidak kekal lama apabila muncul seorang pemimpin yang tidak dapat dinafikan ketokohannya dalam membawa kebangkitan semula Jerman selepas kehancuran negara tersebut pasca perang. Beliau adalah Konrad Adenauer iaitu Canselor Jerman Barat yang pertama (1949-1963) dan digelar sebagai bapa sejarah Jerman moden. Sumbangan Adenauer terhadap Jerman Barat tidak dapat dinafikan sehingga ditegaskan oleh Heck bahawa sesiapa yang ingin bercakap mengenai dasar Jerman selepas Perang Dunia Kedua perlu bermula dengan Konrad Adenauer kerana pencapaian Jerman Barat tidak boleh dipersoalkan lagi hasil kepakaran negarawan ini.

Di sepanjang proses pentadbiran Adenauer, beliau memperlihatkan kemampuan, kebolehan dan keperibadian beliau sebagai seorang pemimpin yang berkaliber melalui pengalaman beliau dalam dunia politik dan latar belakang hidupnya. Kredibiliti yang ada dalam diri Adenauer membolehkan beliau membangunkan semula Jerman pasca perang dengan pelaksanaan dasar domestik dan dasar luar yang berkesan. Kebangkitan semula Jerman membawa kepada penilaian Adenauer sebagai bapa Jerman moden yang merupakan tunjang utama perbincangan makalah ini.

\section{Latar Belakang Konrad Adenauer}

Konrad Adenauer merupakan seorang negarawan yang sangat berpengaruh di pertengahan abad kedua puluh dan mendapat penghormatan sebagai Canselor Jerman Barat selepas Perang Dunia Kedua. Pemilihan Adenauer sebagai Canselor Jerman Barat yang pertama dipengaruhi oleh karakter beliau yang banyak dipengaruhi oleh latar belakang keluarga Adenauer sendiri dan pengalaman hidup beliau.

Konrad Adenauer dilahirkan pada 5 Januari 1876 di Cologne. Bapanya Johann Konrad Adenauer dilahirkan pada tahun 1833 berasal dari Bonn, manakala ibu beliau Maria Christiana Helena Nee Scharfenberg merupakan penduduk asal daerah Cologne. ${ }^{1}$ Adenauer berasal dari keluarga yang sederhana merupakan penganut Roman Katolik dan terdiri daripada lima orang anak iaitu Franz Johann Ludwig August (1872), Johannes Franz Richard (1874), Konrad Adenauer (1876), Emilie Helena Marie Louise Adenauer (1879) dan seorang lagi anak perempuan, Elizabeth (1882), yang telah meninggal dunia ketika berusia empat bulan kerana menghidapi penyakit yang serius. ${ }^{2}$ Didikan Johann dan Helena yang tegas telah membuahkan hasil apabila kesemua anak mereka berjaya dalam hidup dan kejayaan adik-beradik Adenauer ini sangat mempengaruhi kejayaan Adenauer sendiri. 
Konrad Adenauer lahir dalam keluarga yang mementingkan pendidikan sehingga beliau mula mendapat pendidikan awal (mengeja, membaca dan mengira) daripada ayahnya di rumah. Kemudian, Adenauer melanjutkan pelajaran di salah sebuah sekolah yang terkenal di daerah kelahirannya, Cologne iaitu Royal Catholic Gymnasium di Apostles Church atau Aposteln Gymnasium pada tahun 1885. ${ }^{3}$ Setelah berjaya menamatkan sekolah menengah pada 6 Mac 1894, Adenauer layak untuk melanjutkan pelajaran ke peringkat universiti hasil tawaran biasiswa daripada Cologne Education Foundation iaitu dana untuk anakanak Cologne yang berbakat. ${ }^{4}$ Bantuan ini membolehkan Adenauer memilih untuk melanjutkan pelajaran dalam jurusan undang-undang di Universiti Freiburg di Breisgau pada tahun 1894, dan kemudiannya meneruskan pengajian di Universiti Munich pada bulan Ogos 1894 sehingga tahun 1895. Setelah itu, Adenauer layak menduduki peperiksaan undang-undang di Universiti Bonn pada tahun 1895 dan berjaya mendapat gred yang baik dalam peperiksaan tersebut, yang membolehkan beliau menamatkan pembelajarannya pada bulan Mei 1897 ketika berusia 21 tahun. $^{5}$

Pada awal usia 21 tahun, Adenauer memulakan karier beliau sebagai pelatih di Jabatan Perkhidmatan Awam di Cologne, District Court di Brensberg selama lima tahun (1897-1902). Beliau kemudian berkecimpung dalam dunia guaman dan perkhidmatan awam sehingga tahun $1906 .{ }^{6}$ Perkembangan kerjaya Adenauer, turut mempengaruhi kehidupan peribadi beliau apabila Adenauer memutuskan untuk mengakhiri zaman bujangnya ketika berusia 28 tahun dengan mengahwini Emma Weyer. Emma ketika itu berusia 24 tahun yang merupakan anak seorang ahli perniagaan dan ahli politik yang dihormati di Cologne pada 26 Januari $1904 .^{7}$

Perkahwinan ini seterusnya telah membuka peluang Adenauer menceburi bidang politik apabila beliau dilantik sebagai Timbalan Datuk Bandar di Cologne menggantikan Timbalan Datuk Bandar yang bersara secara tiba-tiba. Kerjaya Adenauer semakin berkembang sehingga beliau dilantik menjadi Datuk Bandar Cologne pada bulan Oktober 1917 dan merupakan Datuk Bandar termuda di seluruh Prussia. Setelah Perang Dunia Pertama tamat pada tahun 1920, Adenauer menjadi begitu berpengaruh dan dilantik sebagai ahli Lembaga Republik Weimar yang baru dan dipilih menjadi Presiden Majlis Negeri Prussia pada tahun 1921 sehingga tahun 1933. ${ }^{8}$ Namun, Adenauer telah dilucutkan jawatan sebagai Datuk Bandar Cologne pada tahun 1933 semasa Jerman berada di bawah pengaruh Hitler dan Nationalsozialistische Deutsche Arbeiterpartei (NSDAP) atau dikenali sebagai parti Nazi. Walau bagaimanapun, beliau tetap bergiat aktif dalam Parti Christian Democratic Union (CDU), ${ }^{9}$ sehingga membawa kepada penangkapan 
nya oleh Gestapo dan di tempatkan di kem tahanan selama beberapa bulan pada tahun $1944 .^{10}$

Selepas berakhirnya Perang Dunia Kedua, Adenauer dibebaskan dan memulakan kerjaya beliau semula sebagai Datuk Bandar Cologne di bawah pentadbiran Kerajaan Tentera British pada tahun 1945. Setelah itu, Adenauer kembali bergiat aktif dalam parti CDU dan kemudian dipilih menjadi Canselor Jerman Barat yang pertama pada tahun 1949 ketika usia beliau mencecah 73 tahun. Dalam usia Adenauer yang lanjut, beliau masih gagah memberi sumbangan kepada Jerman yang merupakan sebuah entiti yang telah dua kali mencetuskan perang dunia. ${ }^{11}$

\section{Latar Belakang Negara Jerman}

Jerman sebelum terbentuk sebagai sebuah negara adalah beberapa buah negeri yang mempunyai pentadbiran yang tersendiri. Namun, selepas penyatuan pada tahun 1871 oleh Otto von Bismarck ${ }^{12}$, Jerman muncul sebagai sebuah negara bangsa yang berpengaruh di Eropah. ${ }^{13}$

Keghairahan Jerman memperkukuhkan kekuatan tentera angkatan laut mereka menimbulkan kebimbangan British sehingga membawa kepada penglibatan Jerman dalam Perang Dunia Pertama (1914-1918). Walau bagaimanapun, penyertaan Jerman dalam perang mengalami kekalahan dan membawa kepada kehancuran negara tersebut. Hal ini kerana, Jerman terpaksa memenuhi segala tuntutan kuasa Berikat sebagai pihak yang menang dalam perang, seterusnya meratifikasi Perjanjian Versailles ${ }^{14}$ pada 10 Januari 1920. Pelaksanaan Perjanjian Versailles telah menyebabkan ketidakstabilan Jerman pasca perang dan berterusan sehingga pada awal tahun 1930-an. Namun, rampasan kuasa oleh Adolf Hitler pada tahun 1933, membolehkan Jerman memulihkan kembali keunggulan negara mereka di bawah kuasa dan pengaruh Hitler dan parti Nazi. ${ }^{15}$

Semasa di bawah pentadbiran Hitler dan parti Nazi, mereka telah mengadakan kempen-kempen keganasan bagi mengukuhkan kuasa dan menghapuskan musuh-musuh mereka sehingga dianggap sebagai permulaan era kediktatoran Hitler di Jerman. ${ }^{16}$ Tindakan ini dijalankan bagi merealisasikan rancangan Lebensraum ${ }^{17}$ Hitler. Walau bagaimanapun, keagresifan Hitler bagi mencapai matlamat Lebensraum telah mengheret Jerman dan dunia ke kancah Perang Dunia Kedua pada tahun 1939. Namun, penglibatan Jerman dalam Perang Dunia Kedua telah membawa kekalahan teruk negara tersebut sehingga diletakkan di bawah kuasa Berikat sebagai pihak yang menang selepas perang berakhir. 
Pengalaman dan kecenderungan sejarah sebegini menyebabkan Jerman yang bersatu dilihat berpotensi sebagai ancaman kepada masyarakat dunia dan mampu menggoncang keamanan sejagat. Oleh itu, Jerman telah dibahagikan kepada beberapa zon yang berasingan dan dikuasai oleh pihak Berikat yang terdiri daripada Amerika Syarikat, Soviet Union, Perancis dan Britain pasca perang. ${ }^{18}$ Pembahagian Jerman kepada empat zon akhirnya membentuk dua zon yang berasingan yang dikenali sebagai zon Barat yang dikuasai oleh Amerika Syarikat, Perancis dan Britain, ${ }^{19}$ dan zon Timur yang dikuasai oleh Soviet Union pada tahun 1948. Perpisahan antara dua zon ini bertitik tolak dari permusuhan antara Amerika Syarikat dan Soviet Union dalam pertembungan Perang Dingin yang memuncak pada tahun 1948 apabila tindakan sekatan Berlin dilancarkan oleh Soviet Union. Pembahagian Jerman semakin ketara apabila zon Barat menubuhkan Federal Republic of Germany (FRG) atau dikenali sebagai Jerman Barat secara rasmi pada 9 April 1949 dengan memilih Bonn sebagai ibu negaranya. Manakala zon Timur telah membentuk Germany Democratic Republic (GDR) atau dikenali sebagai Jerman Timur dengan Berlin sebagai ibu negaranya pada 7 Oktober 1949. ${ }^{20}$

Dalam situasi yang sukar ini, Adenauer telah dipilih sebagai Canselor Persekutuan Jerman Barat yang pertama melalui pilihan raya awam yang diadakan pada 15 September 1949. ${ }^{21}$ Pemilihan Adenauer dalam keadaan Jerman yang tidak stabil digambarkan oleh Henry Kissinger dalam bukunya, Diplomacy bahawa; ... it seemed as if his entire life had been a preparation for the responsibility of restoring self-respect to his occupied, demoralized and divided society. ${ }^{22}$ Perlantikan Adenauer sebagai Canselor Jerman Barat (1949-1963) telah membawa kepada pelaksanaan dasar domestik dan dasar luar Jerman bagi membangunkan dan mengembalikan semula kedaulatan Jerman di mata dunia. Kepimpinan dan kebolehan Adenauer ini membolehkan beliau dikenali sebagai bapa sejarah Jerman moden. Ini kerana, di awal pentadbiran Adenauer dari tahun 1949 hingga tahun 1955, Jerman Barat telah hilang kedaulatan, pasukan tentera, kekuatan ekonomi dan kredibiliti moral, sehingga Bonn tidak mempunyai sebarang hak dalam diplomasi. Apa yang dimiliki cuma satu iaitu keupayaan untuk menolak kerjasama dengan sebarang pihak dan bekerjasama dengan pihak Berikat terutamanya Amerika Syarikat.

\section{Sistem Demokrasi}

Tradisi sejarah Jerman membuktikan bahawa negara tersebut kurang pengalaman dalam pelaksanaan sistem demokrasi. Percubaan pelaksanaan sistem demokrasi pertama kali dijalankan semasa di 
bawah pemerintahan Republik Weimar (1919-1933) selepas Perang Dunia Pertama berakhir, namun telah gagal sepenuhnya dalam jangka masa yang singkat kerana mempunyai pelbagai kelemahan ${ }^{23}$. Kegagalan ini memperlihatkan kelemahan pemerintahan Republik Weimar sehingga menyebabkan keruntuhan kerajaan tersebut apabila rakyat bangkit memilih Hitler sebagai Canselor Jerman pada tahun 1933. ${ }^{24}$ Tanpa berlaku rampasan kuasa, sistem demokrasi Jerman dan Republik Weimar yang bertahan lebih dari satu dekad runtuh dengan sendirinya. ${ }^{25}$

Keruntuhan ini seterusnya membawa kepada percubaan kedua pelaksanaan sistem demokrasi di Jerman Barat pada tahun 1949 oleh Konrad Adenauer. ${ }^{26}$ Usaha untuk menerapkan sistem demokrasi di Jerman bermula semasa negara tersebut diletakkan di bawah kawalan tentera Berikat yang banyak memberi pengajaran ${ }^{27}$ dalam merealisasikan pembangunan sistem demokrasi. ${ }^{28}$ Namun, peranan Adenauer untuk merealisasikan sistem demokrasi di Jerman Barat tidak dapat disangkal dan komitmen beliau dapat dilihat dalam surat yang ditulis oleh beliau kepada rakannya, Karl Scharnagl, Datuk Bandar Munich bahawa "I beg you and the other gentlemen to bear in mind continually in your deliberations that only this planned concentration of all forces with a Christian and democratic basis can protect us from the dangers emanating from the East" ${ }^{29}$

Pada awal pelaksanaan sistem demokrasi, Basic Law (Grundgesetz) digubal sebagai perlembagaan rasmi Jerman Barat yang baharu. Semasa proses penggubalan Basic Law, Adenauer bertindak sebagai pengerusi Majlis Parlimen yang merupakan badan yang bertanggungjawab menggubal perlembagaan tersebut. Majlis Parlimen yang mula bersidang pada 1 September 1948 telah berjaya menghasilkan sebuah draf perlembagaan dalam masa sebulan hasil ketegasan dan dedikasi Adenauer selaku ketua majlis. ${ }^{30}$ Draf tersebut kemudiannya diteliti oleh Kerajaan Tentera Berikat dan dimurnikan melalui satu pertemuan antara Adenauer dan Kerajaan Tentera Berikat pada 16 Disember 1948. Hasil perbincangan menghasilkan sebuah memorandum yang bertujuan untuk penambahbaikan draf Basic Law yang sedia ada. Majlis Parlimen seterusnya bersidang untuk kali kedua dan berjaya menyiapkan draf Basic Law yang lengkap pada 11 Februari 1949 setelah menitikberatkan pandangan dan cadangan daripada ahli majlis dan Kerajaan Tentera Berikat. ${ }^{31}$

Persetujuan sebulat suara yang dicapai dalam perbincangan antara Adenauer, Majlis Parlimen, Kerajaan Tentera Berikat dan rakyat Jerman membawa kepada pengesahan Basic Law sebagai perlembagaan rasmi Jerman Barat pada 23 Mei 1949. ${ }^{32}$ Kejayaan ini sangat menggembirakan Adenauer dan dinyatakan oleh beliau semasa ucapannya dalam Majlis Parlimen pada 12 Mei 1949 bahawa "In truth, this probably the first happy 
day since 1933 for us German... Thanked to Western military governors for their quick approval of the Basic Law... and we are finally able to arrange political and governmental matters in at least one part of German according to democratic principle." ${ }^{33}$ Antara keunikan Basic Law ialah ia ditulis oleh rakyat Jerman sendiri dan dokumen Basic Law mengandungi elemen tradisional Jerman iaitu pentadbiran dwi dewan serta ciri-ciri negara demokratik yang baharu dengan memasukkan terma mengenai hak asasi manusia dan pembahagian kuasa kerajaan. Di samping itu, Majlis Parlimen juga telah mempersetujui tarikh pilihan raya yang pertama iaitu pada 14 Ogos 1949 setelah 16 tahun pilihan raya tidak pernah berlangsung di Jerman. ${ }^{34}$

Sistem pilihan raya yang berlangsung 4 tahun sekali di Jerman Barat menunjukkan dominasi Adenauer dan parti Christian Democratic Union (CDU) yang membolehkan beliau dilantik sebagai Canselor Jerman Barat yang pertama pada tahun 1949. ${ }^{35}$ Penguasaan parti CDU berterusan dalam keputusan pilihan raya umum tahun 1953, 1957 dan tahun 1961 mengalahkan The Social Democratic (SPD), diketuai oleh Kurt Schumacher yang merupakan salah satu parti politik yang dominan di Jerman Barat. Kejayaan ini berjaya dicapai hasil kebijaksanaan Adenauer meraih sokongan parti minoriti seperti Free Democratic Party (FDP) dan German Party (DP). Selain itu, keberkesanan manifesto ekonomi iaitu Ekonomi Pasaran Sosial dan integrasi ekonomi Eropah yang mana berjaya mengatasi masalah pengangguran dan krisis ekonomi telah membuka mata rakyat akan kebolehan kepimpinan Adenauer. ${ }^{36}$

Kebolehan dan Kesungguhan Adenauer dalam menjayakan pendemokrasian Jerman akhirnya berjaya membentuk sebuah negara demokratik yang baharu dan moden serta mengikut acuan sendiri. Pendemokrasian Jerman juga berjaya dikekalkan sehingga kini sehingga Adenauer digelar sebagai Chancellor Democracy.

\section{Ekonomi Pasaran Sosial}

Kejayaan sistem demokrasi diteruskan dengan pelaksanaan sistem Ekonomi Pasaran Sosial yang bertujuan untuk memulihkan semula kemelesetan ekonomi dan masalah pengangguran serta menjaga kebajikan sosial masyarakat. Krisis ekonomi Jerman Barat turut diterangkan oleh Preisler dan Keller bahawa;

The period between the spring of 1949 and the spring 1950 may briefly be characterized as a period of general return to normal economic conditions, it was marked by rising output, falling prices, slightly falling profits and unchanged investment; while employment did not continue to rise; it did not fall either, yet unemployment increased. ${ }^{37}$ 
Dasar Ekonomi Pasaran Sosial dimulakan dengan pengenalan sistem mata wang yang baharu, Deutsche Mark (DM) bagi menggantikan mata wang Reichmark pada tahun 1949 oleh Adenauer dan Ludwig Erhard. ${ }^{38}$ Setelah itu, Adenauer cuba memperuntukkan sejumlah wang bagi meningkatkan pelaburan terutamanya dalam industri arang batu, industri perumahan dan infrastruktur pengangkutan. Sebanyak 125 juta DM telah dilaburkan dalam industri perumahan bagi menampung jumlah pelarian yang tidak mempunyai rumah dan seterusnya mampu membuka peluang pekerjaan kepada mereka. Adenauer juga memperuntukkan sebanyak 300 juta DM untuk dilaburkan ke atas perniagaan milik pelarian bagi memacu putaran modal kerajaan, selain membuka peluang-peluang pekerjaan kepada rakyat Jerman Barat bagi menampung kadar pengangguran yang tinggi. Di samping itu, perdagangan bebas asing dalam kalangan negara Eropah turut dibuka pada tahun 1949 yang mana telah melonggarkan beberapa sekatan perdagangan dengan penghapusan kuota dan pengurangan tarif bagi memudahkan perdagangan import-eksport dijalankan. ${ }^{39}$

Kejayaan pelaksanaan Ekonomi Pasaran Sosial membawa kepada pencapaian "miracle economy" di Jerman Barat apabila masalah inflasi dan pengangguran yang berlaku pada tahun 1949 berjaya diatasi dan dapat dilihat melalui penurunan peratusan pengangguran dan peningkatan dalam guna tenaga kerja di Jerman Barat pada jadual di bawah:

Graf Lajur 1: Peratus Pengangguran Jerman Barat, 1949-1963

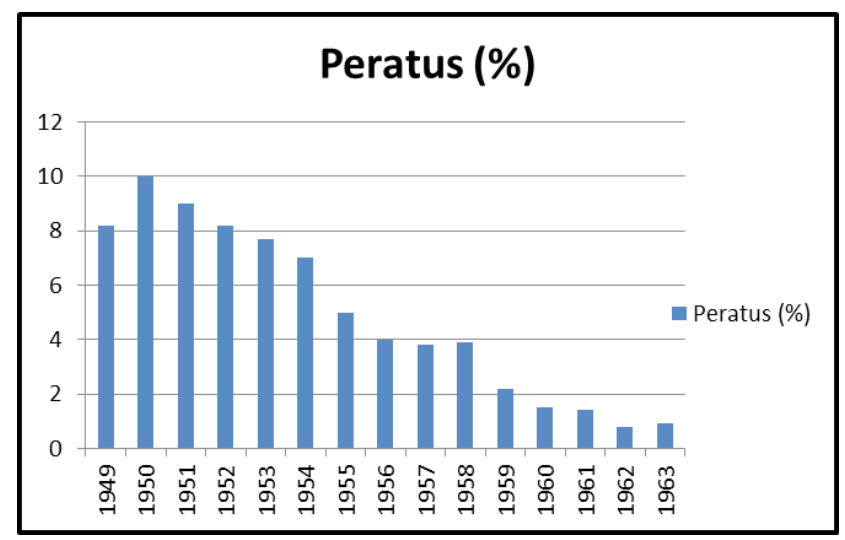

Sumber: J. Bradford De Long, 'Comment on Peter Temin, "The 'Koreaboom' in West Germany: Fact or Fiction?', Berkeley: University of California, 1955, hlm. 5.

Graf di atas menunjukkan kadar peratus pengangguran di Jerman Barat dari 1949 sehingga 1963. Bermula pada tahun 1949 kadar 
pengangguran semakin meningkat iaitu seramai 1.5 juta orang sehingga mencecah 2 juta orang pada tahun 1950. Walau bagaimanapun, selepas pengenalan Ekonomi Pasaran Sosial dan pelaksanaan kerjasama ekonomi ECSC, peratus pengangguran semakin menurun sehingga mencapai tahap minimum antara tahun 1955 sehingga tahun 1963.

Kemakmuran ekonomi yang dicapai oleh Jerman Barat seterusnya turut dijelaskan dalam liputan akhbar pada 7 September 1953 bahawa; "five years of hard labor lie behind us, but they were not in vain. The ghost of unemployment had been banned. Three million new jobs were created. Five million people got new housing... It is therefore necessary to secure our peaceful reconstruction." 40 Seterusnya, pencapaian ekonomi Jerman Barat juga didorong oleh peribadi Adenauer yang mudah berkompromi dengan pihak Barat yang membolehkan integrasi Eropah dijalankan dalam bidang ekonomi dan ketenteraan.

\section{Integrasi Eropah}

Adenauer sangat sinonim dengan usaha integrasi Eropah kerana beliau dilihat sebagai tenaga yang banyak mendorong ke arah pembentukan integrasi tersebut. Dasar pengintegrasian ini sangat penting dalam memastikan pemodenan dan kedaulatan Jerman Barat berjaya dipulihkan dengan mendapatkan semula kepercayaan negara-negara Eropah khususnya dan dunia amnya untuk menjalinkan kerjasama dan hubungan baik dengan Bonn. Hal ini dijelaskan oleh Merkl bahawa, “... The main elements of [Adenauer] policy were a close alliance with the USA, reconciliation with France, and the establishment of increasingly close economic and political ties with the Federal Republic's Western European neighbors..."

Integrasi Jerman Barat dengan beberapa negara di Eropah bermula dengan usaha mengintegrasikan ekonomi Perancis-Jerman Barat sehingga membentuk Komuniti Arang Batu dan Keluli Eropah atau European Coal and Steel Community (ECSC) pada tahun 1951. Kerjasama ini bermula rentetan perjumpaan sulit antara Adenauer dan Robert Schuman ${ }^{42}$ semasa Kongres Pergerakan Eropah yang pertama berlangsung pada bulan Oktober 1948. Dalam perjumpaan tersebut, Adenauer menyatakan keinginan beliau untuk melaksanakan kerjasama tersebut, namun ia sukar untuk direalisasikan sekiranya Perancis masih meletakkan kawalan mereka ke atas daerah Saar. ${ }^{43} \mathrm{Hal}$ yang sama turut dinyatakan oleh Adenauer kepada Kingsbury Smith, wartawan kanan Amerika Syarikat pada 7 Mac 1950 bahawa beliau ingin melihat penubuhan kesatuan kastam Perancis-Jerman yang diselia oleh Kementerian Ekonomi antara kedua buah negara;

A union between France and Germany would give new life and vigour to a Europe that is seriously ill. It would have an immense psychological and 
material influence and would liberate powers that are sure to save Europe. I believe this is the only way of achieving the unity of Europe. It would cause the rivalry between two countries to disappear. ${ }^{44}$

Keinginan Adenauer untuk menjalinkan hubungan kerjasama dalam kalangan negara Eropah Barat menjadi realiti apabila Jean Monnet, Perancang Ekonomi Perancis dan rakan-rakannya menghasilkan sebuah kertas cadangan ke arah pembentukan ECSC dalam kalangan negara Eropah. ${ }^{45}$ Kertas cadangan tersebut diserahkan kepada Schuman dan beliau bersetuju setelah meneliti kertas cadangan tersebut yang dikenali sebagai Schuman Plan atau Rancangan Schuman. Bagi menjayakan rancangan tersebut, Schuman telah menghantar utusan sulit ke Jerman Barat untuk menemui Adenauer kerana beliau melihat Adenauer sebagai kunci kejayaan dan kegagalan pembentukan kerjasama ECSC. Dua pucuk surat rasmi telah disampaikan oleh Schuman kepada Adenauer pada 9 Mei 1950, satu daripada surat tersebut adalah surat peribadi Schuman dan sepucuk surat lagi merupakan salinan cadangan pembentukan ECSC atau dikenali sebagai Schuman Plan. ${ }^{46}$

Setelah Adenauer meneliti cadangan ECSC, beliau mengambil keputusan untuk memberi maklum balas positif kepada Schuman melalui sepucuk surat rasmi dan sepucuk surat persendirian, dengan mengatakan bahawa; "[Adenauer] welcomes Foreign Minister Schuman initiative, and he is in complete agreement with the basic idea and the general tendency of his plan." 47 Respons positif yang ditunjukkan oleh Adenauer kerana beliau menyedari inisiatif yang dijalankan oleh Schuman sejajar dengan matlamat kerjasama yang beliau inginkan. ${ }^{48}$ Komitmen Adenauer dalam menjayakan kerjasama ekonomi tersebut membawa kepada pembentukan ECSC secara rasmi yang diumumkan oleh Schuman semasa mesyuarat kabinet Perancis di Quai d'Orsay pada 9 Mei 1950. ECSC telah dianggotai oleh Jerman Barat, Perancis, Itali, Belgium, Netherland dan Luxembourg (Benelux) atau yang dikenali sebagai The Six dan dilaksanakan secara rasmi pada 23 Jun $1952 .{ }^{49}$

Pelaksanaan ECSC telah memberi impak yang positif terhadap ekonomi dan sosial dalam kalangan negara anggota. Selain peningkatan dalam pengeluaran komoditi tersebut, ECSC turut membawa kepada perkembangan taraf hidup masyarakat, pengurangan kadar pengangguran dan peningkatan dalam kebajikan masyarakat negara anggota. Kejayaan perlaksanaan ECSC merupakan satu langkah besar ke arah merealisasikan matlamat Adenauer untuk mengintegrasikan Eropah Barat dari sudut ekonomi, politik dan pertahanan. Bagi menjayakan matlamat tersebut, kerjasama diteruskan dalam aspek pertahanan yang membawa kepada pembentukan European Defense Community (EDC) oleh The Six. 
Idea pembentukan semula angkatan tentera Jerman Barat telah dicadangkan oleh Setiausaha Luar Negara Amerika Syarikat, Dean Acheson semasa mesyuarat Majlis NATO yang diadakan New York. Namun, cadangan Acheson telah mengejutkan ahli persidangan dan mendapat bantahan daripada sebahagian ahli persidangan. Walau bagaimanapun, desakan Perang Korea yang tercetus pada 25 Jun 1950 menimbulkan kebimbangan semua pihak terutamanya Amerika Syarikat dan membawa kepada cadangan Adenauer agar penubuhan angkatan pertahanan Jerman Barat semasa Persidangan Pesuruhjaya Tinggi Berikat yang diadakan pada 17 Ogos 1950. Sehubungan itu, Amerika Syarikat telah mencadangkan agar persenjataan semula Jerman Barat dijalankan semasa Persidangan Menteri Luar Berikat di New York ${ }^{50}$ yang diadakan pada 12 September $1950 .{ }^{51}$ Walau bagaimanapun, cadangan Adenauer, McCloy dan Acheson mendapat bantahan dari Setiausaha Luar Negara British, Ernest Bevin dan Schuman bahawa; "Germany must be led back into the community of nations, but that [We] did not believe the corporation of German military units into the armed forces of western Europe to be the right way." 52

Oleh yang demikian, sebuah rancangan telah dirangka yang mana memberi kuasa kepada Rene Pleven menyediakan sebuah kertas kerja pertahanan Eropah untuk diusulkan dalam Perhimpunan Kebangsaan Perancis. Draf cadangan Pleven akhirnya dipersetujui oleh Perhimpunan Kebangsaan Perancis pada 24 Oktober 1950 dan dikenali sebagai Pleven Plan. ${ }^{53}$ Rancangan Pleven seterusnya mendapat persetujuan Adenauer dan membawa kepada persetujuan Kerajaan Tentera Berikat terhadap penyertaan Jerman Barat dalam EDC selepas beberapa kali mengadakan perbincangan pada 19 Disember 1950, 24 Januari 1951 dan 10 hingga 14 September 1951. Meskipun begitu, usaha Adenauer menemui kegagalan apabila Perjanjian EDC enggan diratifikasi oleh Perancis dan menemui jalan buntu yang akhirnya menyebabkan EDC gagal sepenuhnya pada 30 Ogos 1954.

Adenauer tidak melihat kegagalan kerjasama EDC sebagai jalan muktamad kepada Jerman Barat untuk menjayakan pembangunan semula pertahanan dan persenjataan negara tersebut. Hal ini kerana selepas kegagalan EDC, Jerman Barat telah diterima sebagai ahli NATO setelah berulang kali didesak oleh Adenauer dan Amerika Syarikat yang semakin terancam dengan perluasan ideologi Komunis. Oleh itu pada bulan Oktober 1954, Majlis NATO bertindak menjemput Jerman menganggotai NATO dan membawa kepada pembentukan angkatan tentera Jerman dalam rangka kerja pertahanan NATO pada bulan November $1954 . .^{54}$ Setelah itu pada 6 Mei 1955, Jerman Barat secara rasmi menyertai NATO selepas menandatangani Pakatan Brussels, sekali gus menamatkan Statut Pendudukan Berikat di Jerman Barat. 
Selain mengiktiraf Jerman Barat bukan lagi sebagai musuh dunia tetapi merupakan negara bebas dalam kalangan kuasa-kuasa Barat serta menjadi rakan dan sekutu dalam perjuangan menentang blok Timur. ${ }^{55}$ Penerimaan kuasa Barat terhadap penyertaan Jerman Barat dalam NATO sangat dihargai oleh Adenauer dan rakyat Jerman yang mulai merasa kedaulatan negara mereka diiktiraf oleh dunia.

Kejayaan Adenauer merealisasikan pertahanan semula Jerman Barat turut diikuti dalam kerjasama ekonomi dalam konteks yang lebih luas melalui penubuhan European Economic Community (EEC) pada 25 Mac 1957. Pembentukan EEC didorong daripada kerjasama yang dijalinkan oleh Adenauer dan de Gaulle selaku Perdana Menteri Perancis yang baru dilantik pada tahun 1958. Keterbukaan kedua-dua pemimpin ini melalui perbincangan dan lawatan antara negara serta didorong oleh persamaan matlamat perjuangan mereka. Pelaksanaan EEC bermula dengan pembukaan dasar perdagangan bebas dalam kalangan negara anggota yang mana beberapa sekatan perdagangan dihapuskan dan pengurangan tarif dijalankan. ${ }^{56}$ Seterusnya, dasar pertanian yang dikenali sebagai Common Agricultural Policy (CAP) diperkenalkan yang membolehkan para petani yang kurang produktif dilindungi. ${ }^{57}$ Perjanjian yang dimeterai antara Adenauer dan de Gaulle dalam CAP sedikit sebanyak telah mengukuhkan lagi persahabatan mereka. Hal ini kerana, CAP telah berjaya mencapai apa yang diingini untuk para petani negara mereka dan menunjukkan komitmen mereka untuk merealisasikan EEC. Kejayaan CAP dinyatakan oleh Adenauer semasa di Bundestag pada 17 Januari 1962 bahawa "economic achievement of the Community including the agreements on agriculture, constituted 'one of the most important events in European history in recent centuries, because they mark a major step forward the realization of political union."58

Sepanjang 11 tahun pelaksanaan EEC yang bermula pada tahun 1958 dan berakhir pada tahun 1969, menunjukkan kesan yang positif iaitu peningkatan ekonomi setiap negara anggota sehingga berjaya mencapai hampir semua matlamat EEC lebih awal dari jangkaan mereka iaitu pada tahun 1970. Kejayaan EEC ini juga telah membentuk sebuah hubungan istimewa antara negara Jerman dengan Perancis yang telah memeterai sebuah perjanjian persahabatan yang dikenali sebagai Elysée Treaty pada 22 Januari 1963. ${ }^{59}$ Melalui perjanjian ini, kedua belah pihak bersetuju untuk mengakhiri permusuhan tradisional antara kedua buah negara yang telah berlangsung selama beratus-ratus tahun dahulu. ${ }^{60}$

Pemulihan hubungan diplomatik antara Jerman dengan Perancis, turut mendorong Adenauer untuk menyatukan semula Jerman Barat dengan Jerman Timur sebagai langkah terakhir ke arah pembentukan sebuah negara Jerman yang moden dan bersatu. Bagi menjayakan hubungan tersebut, dasar Ostpolitik iaitu dasar pandang ke Timur telah 
dilaksanakan oleh Adenauer pada pertengahan tahun 1950-an. Dasar Ostpolitik dimulakan dengan siri lawatan Adenauer ke Moscow bertemu dengan pemimpin kesatuan Soviet pada 8 September 1955. Pada 25 April 1958, Adenauer telah mengadakan rundingan dengan pemimpin Soviet Union di Kremlin yang mana telah menghasilkan sebuah perjanjian Jerman Barat-Kesatuan Soviet mengenai perdagangan, kedutaan dan hal ehwal kebudayaan yang ditandatangani di Bonn. Walau bagaimanapun, keghairahan Soviet Union di bawah pentadbiran Nikita Khrushchev untuk menjadikan Jerman Barat sebagai "bandar bebas" bagi menghilangkan pengaruh Barat di negara tersebut dan menginginkan Jerman terbahagi kepada tiga "negara" yang mana Jerman Barat menjadi "negara" ketiga, membawa kepada perasaan tidak puas hati Adenauer. Hal ini menyebabkan Soviet Union bertindak membina Tembok Berlin pada 13 Ogos 1961 bagi memisahkan Jerman Barat dan Jerman Timur secara fizikal. ${ }^{61}$

Ketelanjuran tindakan Khrushchev telah menyebabkan matlamat Adenauer untuk menjayakan penyatuan semula dua entiti Jerman yang telah terpisah menemui kegagalan. Meskipun begitu, kegagalan ini bukanlah titik penilai bahawa Adenauer merupakan seorang pemimpin yang lemah. Ini kerana, peranan Adenauer dalam membangunkan kembali negara Jerman yang moden dan makmur tidak dapat disangkal lagi sehingga beliau dikenali sebagai bapa Jerman moden. Walau bagaimanapun, kejayaan Adenauer memulihkan kembali negara Jerman bukanlah semata-mata atas usaha dan kesungguhan beliau sendiri, kerana ia juga turut didorong oleh situasi antarabangsa yang berlaku di Eropah ketika itu.

\section{Situasi Antarabangsa}

Perang Dingin yang berlangsung di Eropah menyebabkan Amerika Syarikat melaksanakan dasar "pembendungan" bagi mengekang perluasan pengaruh Komunis dan memperluaskan pengaruh Barat di Eropah dan Asia. Bagi menjayakan rancangan tersebut, saluran bantuan melalui Rancangan Marshall dilancarkan dan Jerman Barat merupakan salah sebuah negara yang turut menerima bantuan tersebut iaitu sebanyak 3.3 juta Dolar. ${ }^{62}$ Bantuan kewangan ini digunakan oleh Adenauer untuk memulihkan semula ekonomi Jerman Barat dengan melaburkan sejumlah wang untuk pembangunan sektor industri, pemberian pinjaman dan menaik taraf sektor perumahan dan sumber tenaga kepada rakyat. Hal ini membawa kepada pembukaan peluang-peluang pekerjaan yang membolehkan golongan bawahan menampung kehidupan mereka dan turut mengatasi masalah lambakan pengangguran yang dialami oleh Jerman Barat. 
Komitmen Amerika Syarikat menghapuskan pengaruh Komunis juga membolehkan Jerman Barat diterima sebagai ahli NATO dan rakan pakatan menentang Soviet Union. Hal ini kerana Amerika Syarikat melihat Adenauer mempunyai matlamat yang sama dengan perjuangan mereka. Hal ini dinyatakan oleh Rupierer bahawa:

In this difficult situation, Adenauer became Washington's biggest asset. His loyal support for the policy of Western integration was the German pillar of U.S policy. Unlike any other German politician, Adenauer identified his political future with integration, rapprochement with France, and the leading role of the United States in Europe. The chancellor never left any doubt that European integration was an unrenounceable political demand I order to strengthen Europe, to force a permanent linkage between the Germans and the west, and thus to prevent Soviet domination of all Europe. ${ }^{63}$

Di samping itu, Perang Korea yang tercetus pada bulan Jun 1950 turut memberi impak positif terhadap pertahanan dan ekonomi Jerman Barat. Hal ini kerana, Amerika Syarikat mulai melihat kestrategikan Jerman Barat sebagai kawasan penampan perluasan ideologi Komunis di Eropah Barat dan sebagai pembekal peralatan perang dan pengeluar indusri berat. Kebergantungan Amerika Syarikat terhadap Jerman Barat membolehkan Adenauer memanipulasi peluang yang ada dengan menjayakan persenjataan dan pertahanan semula Jerman Barat dan memakmurkan kembali ekonomi mereka yang runtuh pasca perang. Kebolehan Adenauer mengoptimumkan ruang dan peluang yang diberikan oleh Amerika Syarikat menonjolkan kehebatan beliau sebagai seorang pemimpin yang bijak, berpandangan jauh dan optimistik dalam membangunkan kembali Jerman Barat.

\section{Kesimpulan}

Konrad Adenauer merupakan bapa sejarah Jerman moden yang telah berjaya memulihkan semula kedaulatan dan membangunkan kembali Jerman Barat yang baharu setelah musnah teruk semasa Perang Dunia Kedua. Kehadiran Adenauer sebagai seorang pemimpin yang berkaliber, bijak dan berpengalaman membolehkan dasar domestik dan dasar luar yang berkesan dijalankan di Jerman Barat. Kejayaan dasar domestik dan dasar luar Jerman Barat membawa kepada kelahiran sebuah negara demokratik yang baharu, kekayaan dan kemakmuran ekonomi serta hubungan diplomatik yang harmoni dalam jangka masa 14 tahun pentadbiran Adenauer. 
Walau bagaimanapun, kejayaan ini bukanlah hanya dominasi usaha dan komitmen Adenauer sahaja. Ini kerana pada masa yang sama pengaruh Amerika Syarikat dalam setiap pelaksanaan dasar domestik dan dasar luar Jerman Barat juga tidak dapat dinafikan. Pendek kata, kedua-kedua faktor ini saling berkaitan dan berkepentingan dalam menjayakan semula kemakmuran Jerman Barat. Namun, kredibiliti dan pengalaman Adenauer sememangnya telah membuktikan kebolehan beliau sebagai seorang pemimpin yang berkaliber dan bukanlah boneka yang berkuasa atas arahan Amerika Syarikat. Ketokohan Adenauer juga terserlah sebagai seorang pemimpin yang sangat mudah berkompromi, tetapi "licik" dalam memaksimumkan kuasa dan kepercayaan yang diberikan oleh Amerika Syarikat kepadanya. Selain mampu menonjolkan kelebihan idea dan prinsip yang dipegang oleh beliau walaupun bekerja di bawah kawalan kuasa besar dunia. Walau bagaimanapun, peranan yang dimainkan oleh Amerika Syarikat juga sangat signifikan sebagai medium mempercepatkan lagi kebangkitan Jerman pasca Perang Dunia Kedua. Berikutan keadaan Jerman yang "kosong" pada tahun 1945 sehingga mampu mencapai tahap negara maju dan moden pada tahun 1963.

\section{Nota}

1 Paul Shippy, 'Konrad Adenauer: Strong Leader and Principles Statesman', History of the Western World II, Jil. 140, No. 12, 2005, hlm. 1 dan Charles Williams, Adenauer: the Father of the New Germany, New York: John Wiley dan Sons Inc., 2000, hlm. 3.

2 Hans-Peter Schwarz, Konrad Adenauer: A German Politician and Statesman in a Period of War, Revolution and Reconstruction, United Kingdom: Berghann Books, 1995, hlm. 35- 42.

3 Ronald Irving, Adenauer: Profiles in Power, London: Pearson Education Limited, 2002, hlm. 5.

4 Charles Williams, Adenauer: the Father of the New Germany, hlm. 24-25.

$5 \quad$ Hans-Peter Schwarz, Konrad Adenauer: A German Politician, hlm. 61.

6 Ibid., hlm. 67.

7 Paul Shippy, 'Konrad Adenauer: Strong Leader and Principles Statesman', hlm. 1.

Ibid.

Penglibatan aktif Adenauer dalam Christian Democratic Union (CDU) adalah bertitik-tolak dari pengaruh agama Kristian yang kuat dari ayahnya, Johann Konrad dan penglibatan beliau dalam Persatuan Katolik. Pegangan ajaran Kristian yang teguh dalam keluarga Adenauer sehingga dikatakan oleh Williams bahawa, "Johann dan keluarganya akan bersembahyang di rumah pada waktu pagi dan petang setiap hari dan setiap kali Johann pulang dari tempat kerja, beliau akan singgah melawat dan berdoa di Black Madonna, Kupfergasse. Setelah itu semasa di 
universiti, Adenauer dilantik menjadi Bendahari Persatuan Pelajar Katolik kerana kemahiran beliau mengendalikan belanjawan hasil pengalaman sebagai perantis bank. Pengalaman dan pegangan agama Adenauer membolehkan beliau terlibat aktif dalam persatuan Parti Pusat untuk rakyat Kristian di Cologne pada tahun 1906 yang akhirnya membentuk Christian Democratic Union (CDU). Penyertaan Adenauer dalam CDU menyebabkan beliau aktif dalam dunia politik sehingga dilantik menjadi pengerusi CDU di zon pendudukan British pada tahun 1946 dan pengerusi CDU Jerman Barat pada tahun 1949. Charles Williams, Adenauer: the Father of the New Germany, hlm. 6 dan Ronald Irving, Adenauer: Profiles in Power, hlm. 2.

Paul Shippy, 'Konrad Adenauer: Strong Leader and Principles Statesman' hlm. 2 dan T.n.p, Konrad Adenauer/Klaus Gotto, Bonn: Aktuell, 1994, hlm. 20.

Ibid.

12 Otto von Bismarck atau nama sebenar beliau Otto Eduard Leopold von Bismarck merupakan Perdana Menteri Prussia dan seorang pemerintah yang kuku besi dan diktator. Bismarck dilantik menjadi Canselor Jerman pada tahun 1871 setelah berjaya menyatukan Jerman sebagai sebuah empayar. Bagi mengukuhkan empayar Jerman, Bismarck telah menjalankan dasar luar yang licik melalui perimbangan kuasa secara aman dan berkepentingan yang bertujuan mengangkat Jerman sebagai sebuah kuasa besar di Eropah. Walau bagaimanapun, perbezaan pandangan dalam pelaksanaan dasar (anti-sosialis dan dasar perluasan kuasa) antara Adenauer dengan William II (Maharaja Jerman yang baru) membawa kepada peletakan jawatan Bismarck pada tahun 1890. Lynn Abraham, Bismarck and The German Empire 1871-1918, New York: Routledge, 2006, hlm. 26.

Jerman muncul sebagai sebuah negara bangsa selepas penyatuan beberapa buah daerah. Bermula semasa penguasaan Napoleon Bonaparte I, tiga ratus buah negeri kecil Jerman telah melepaskan diri daripada naungan Austria dan mencapai kemerdekaan pada tahun 1789. Selepas Kongres Vienna 1815 diadakan, beberapa buah negeri telah digabungkan selepas berlakunya proses penaklukan sehingga membentuk tiga puluh lima buah negeri, dan kemudian tinggal tujuh belas buah negeri pada tahun 1848 . Dari tujuh belas buah negeri, Prussia muncul sebagai sebuah negeri yang mempunyai kuasa kedua terkuat selepas Austria telah menjadi perintis ke arah penyatuan Jerman oleh Bismarck. Kejayaan Prussia membentuk Jerman sebagai sebuah negara bangsa pada 18 Januari 1971 di Versailles, telah menyaksikan penguasaan Jerman di Eropah. Lihat, Ibid., hlm. 86 dan Qasim Ahmad, Eropah Moden : Arus Sosiopolitik dan Pemerintahan, Ed. Ke-2, Kuala Lumpur: Dewan Bahasa dan Pustaka, 1997, hlm. 63.

14 Di bawah Perjanjian Versailles, Jerman Barat Jerman kehilangan banyak tanah jajahan dan penduduknya. Begitu juga dengan sumber ekonomi yang turut terjejas ekoran daripada kehilangan daerah yang kaya dengan aktiviti perlombongan arang batu dan besi. Selain itu, Jerman juga terpaksa membayar ganti rugi perang kepada pihak Berikat iaitu sebanyak 
132 bilion Gold Marks secara beransur-ansur. Keadaan ini secara tidak langsung telah menambahkan lagi beban kewangan Jerman, di samping terpaksa menampung kos perbelanjaan yang tinggi bagi memulihkan infrastruktur negara berkenaan yang musnah akibat pengeboman semasa peperangan. Perjanjian Versailles juga menyebabkan Jerman dikenakan tindakan perlucutan senjata secara bersyarat dan larangan untuk memiliki angkatan tentera. Hal ini bertujuan untuk melemahkan kuasa ketenteraan Jerman yang dianggap mampu menggugat kedudukan pihak Berikat dan menghalang Jerman menjadi kuasa besar di Eropah. W A. Coupe, 'German Cartoonists and the Peace of Versailles', History Today, 1982, hlm. 47 dan Alfons Heck, A Child of Hitler: Germany in the Days When God Wore a Swastika, Arizona: Renaissance House Publishers, 1985, hlm. 2. David Stevenson, 'Britain, France and the Origins of German Disarmament, 1916-1933', The Journal of Strategic Studies, Jil. 29, No. 2, 2006, hlm. 204 dan W A. Coupe, 'German Cartoonists and the Peace of Versailles', hlm. 47. Williamson Murray, 'The Making of Hitler's Army', Military History, 2008, hlm. 31.

17 Lebensraum bermaksud ruang hidup atau living space yang diilhamkan oleh Hitler untuk mendapatkan penempatan yang selesa untuk orang Jerman. Hitler percaya bahawa orang Jerman berasal dari bangsa Aryan. Penempatan ini penting untuk menampung kelangsungan hidup masyarakat Jerman secara fizikal, politik dan ekonomi serta memastikan negara itu megah di pentas dunia. Bagi menjayakan dasar Lebensraum tersebut, Hitler perlu melancarkan serangan ke atas Rusia, Eropah Timur dan kawasan Baltik yang dikenali sebagai space of destiny yang dikatakan tanah yang paling sesuai untuk mendapatkan ruang hidup untuk orang Jerman. Selain bertujuan untuk mengangkat Jerman sebagai sebuah kuasa yang berpengaruh di dunia. Charles Kruszewski, 'International Affairs: Germany's Lebensraum, The American Political Science Review', Jil. 34, No. 5, 1940, hlm. 964, Martyn Housden, 'Lebensraum: Policy or Rhetoric?', History Today, 2001, hlm. 28 dan Woodruff D. Smith, 'Friedrich Ratzel and the Origins of Lebensraum', German Studies Review, Jil. 13, No. 1, 1980, hlm. 51.

M E. Bathurst, 'Legislation in the Federal Republic of Germany', The International and Comparative Law Quarterly, Jil. 1, No. 1, 1952, hlm. 42 . Penyatuan zon Barat yang dikuasai oleh Amerika Syarikat, Perancis dan Britain bermula apabila Kerajaan Tentera British dan Amerika Syarikat bergabung secara rasmi pada 1 Januari 1947 membentuk pasaran ekonomi tunggal yang dikenali sebagai Bizonal Economic Council atau Bizonia. Setelah itu, Perancis dimasukkan dan membentuk gabungan yang dikenali sebagai Trizone (Triple Zone). Akhirnya, kerjasama direalisasikan di London pada Mac 1948 oleh Amerika Syarikat, Perancis dan British yang bersepakat untuk bersatu padu. Hans G. Heymann, 'Germany: From Destruction to Democracy', Vital Speeches of the Day, Jun 1967, hlm. 667 dan M E. Bathurst, 'Legislation in the Federal Republic of Germany', hlm. 41. 
$20 \quad$ Ibid., hlm. 42 dan Elmer Plischke, 'Reunifying Germany-An Options Analysis', World Affairs, Jil. 132, No. 1, 1969, hlm. 28.

21 Konrad Kellen, 'Adenauer At 90', Foreign Affairs, Jil. 44, No. 2, 1966, hlm. 275.

Henry Kissinger, Diplomacy, New York: Simon dan Schuster, 1994, hlm. 502.

Antara kelemahan yang ketara semasa pelaksanaan sistem demokrasi Weimar ialah ketidakcekapan pentadbiran Republik Weimar sendiri apabila birokrasi kerajaan, badan kehakiman dan pegawai-pegawai polis tidak diperkenalkan ke arah pentadbiran yang demokrasi. Begitu juga dengan ahli-ahli politik Jerman yang enggan berkompromi dan bersifat autokratik, serta sikap masyarakat Jerman sendiri yang enggan menerima kerajaan demokrat sosial dan pemerintahan Republik Weimar kerana menganggap masyarakat Jerman akan mengakui kemenangan pihak Berikat dalam Perang Dunia Pertama dan terpaksa menerima Perjanjian Versailles yang dianggap berat sebelah dan menindas rakyat Jerman. Seterusnya, masalah ekonomi Jerman yang teruk telah memberi Great Depression kepada negara dan rakyat Jerman sehingga membawa kepada kemelesetan ekonomi yang teruk. C R. Hiscocks, 'The Development of Democracy in Western Germany Since the Second World War', The Canadian Journal of Economics and Political Science, Jil. 20, No. 4, 1954, hlm. 494.

Dick Geary, 'Who Votes For the Nazi's?', History Today, 1998, hlm. 9. Bundesrepublik to Deutschland: German Politics After Unification, Michigan: University of Michigan Press, 1993, hlm. 33 dan C R. Hiscocks, 'The Development of Democracy', hlm. 494.

26 Ibid., hlm. 498.

$27 \quad$ Antara pengajaran yang diterapkan oleh pihak Berikat bagi merealisasikan sistem demokrasi di Jerman Barat dengan mengubah mentaliti dan intelek rakyat Jerman yang selama ini dikuasai oleh parti Nazi dengan memperkenalkan sistem demokrasi di negara tersebut. Antaranya mengadakan sistem pilihan raya di peringkat majlis perbandaran dan majlis daerah terutamanya di kawasan zon Barat serta memperkenalkan undang-undang yang dikenali dengan Land Constitution iaitu sebagai perlembagaan negeri di zon pendudukan Kerajaan Tentera Amerika Syarikat. Jefry M. Diefendorf dan Axel Frohn, American Policy and the Reconstruction of West Germany, 1945-1955, New York: Press Syndicate of the University of Cambridge, 1993, hlm. 87, Frank Roy. Willis, The French in Germany, California: Stanford University Press, 1962, hlm. 109 dan Kurt Duwell, 'Germany 1945-1950: Problems of the 'Economic Miracle', History Today, September 1983, hlm. 5.

28 Ibid.

29 Geoffrey Pridham, Christian Democracy in Western Germany, London: Croom Helm Ltd., 1977, hlm. 30.

30 Beath Ruhm von Oppen (terj) Konrad Adenauer: Memoirs 1945-53, Chicago: Henry Regnery Company, 1966, hlm. 121-122. 
$31 \quad$ Ibid., hlm. 136-137 \& Terence Prittie, Terence Prittie, Konrad Adenauer 18761967, Chicago: Cowles Book Company, 1971, hlm. 136, John F. Golay, The Founding of the Federal Republic of Germany, Chicago, 1958, hlm. 217-223, 250, 254 \& 258-259 dan Letter from the Military Governors to Dr. Konrad Adenauer, President of the Parliamentary Council, approving the Basic Law (May 12, 1949), Federal Constitution, hlm. 138.

32 M E. Bathurst, 'Legislation in the Federal Republic of Germany', hlm. 41.

33 Statement by Konrad Adenauer at the Meeting of Military Governors, Representatives of the Parliamentary Council, and Minister Presidents (May 12, 1949), Federal Constitution, hlm. 137, Beath Ruhm von Oppen (eds.), Documents on Germany Under Occupation 1945-1954, London and New York: Oxford University Press, 1955, hlm. 390-92, Hans-Peter Schwarz(b), Konrad Adenauer: From the German Empire to the Federal Republic, 1876-1952, United Kingdon: Berghahn Books, 1995, hlm. 419. John F. Golay, The Founding of the Federal Republic, hlm 226-227. Fritz Rene Allemann, 'Election Year in West Germany', The World Today, Jil. 21, No. 5, 1953, hlm. 179. C R. Hiscocks, 'The Development of Democracy in Western Germany', hlm. 501. Horst Friedrich Wunsche, Standard Texts on the Social Market Economy, New York: Gustav Fisher Verlag, 1982, hlm. 33. Der Spiegel, 06 Disember 1950, Armin Grunbacher, 'Profits and Cold WarPolitically Motivated Export Finance in West Germany during the 1950s: Two Case Studies', German Politics, Jil. 10, No. 3, 2001, hlm. 142, Konrad Zweig, The Origins of the German Social Market Economy: the Leading Ideas and Their Intellectual Roots, London: Adam Smith Institute, 1980, hlm. 17 James C. Van Hook, Rebuilding Germany: the Creation of the Social Market Economy (1945-1957), Cambridge: Cambridge University Press, 2004, hlm. 211-212.

40 Guido Thiemeyer, "The "Social Market Economy" and its Impact on German European Policy in the Adenauer Era 1949-1963', German Politics and Society, Jil. 25, No. 2, 2007, hlm. 70-71.

41 Peter H. Merkl, German Foreign Policies, West dan East: On the Threshold of a New European Era, California: American Bibliographical-Clio Press Inc, 1974, hlm.83.

42 Robert Schuman merupakan Menteri Luar Perancis antara tahun 1948 sehingga 1952. Schuman dilahirkan pada 29 Jun 1886 di Luxembourg dan digelar juga sebagai Bapa Kesatuan Eropah kerana beliau bertanggungjawab menjayakan kerjasama ekonomi pertama Eropah iaitu ECSC dan menyokong penuh integrasi Eropah yang dijalankan dalam kalangan negara Eropah. T.n.p, Robert Schuman: the Architect of the European Integration project, dalam The Founding Fathers of the EU, European Commission, (t.t), hlm. 1.

43 Ronald Irving, Adenauer: Profiles in Power, hlm. 113.

$44 \quad$ Ibid., \& Beate Ruhm von Oppen (terj.), Konrad Adenauer: Memoirs 1945-53, hlm. 244-245. 
45 Karen J. Alter \& David Steinberg, The Theory and Reality of the European Coal and Steel Community, Buffett Center for International and Comparative Studies Working Paper Series, Northwestern University, January 2007, hlm. 5 .

46 Ronald Irving, Adenauer: Profiles in Power, hlm. 113-114, Beate Ruhm von Oppen (terj), Konrad Adenauer: Memoirs 1945-53, hlm. 257 \& Paul Weymar, Konrad Adenauer: The Authorized Biography, London: Andre Deutsh Limited, 1957, hlm. 347-348.

$47 \quad$ Ibid., hlm. 349.

48 Ronald Irving, Adenauer: Profiles in Power, hlm. 114.

49 Roy Willis, 'Germany, France and Europe', dalam Wolfram F. Hanriedar, West German Foreign Policy (1949-1979), Colo: Westview Press, 1980, hlm. 93, John Gillingham, Coal, steel, and the Rebirth of Europe 1945-1955: The Germans and French From Ruhr Conflict, to Economic Community, United Kingdom: Cambridge University Press, 1991, hlm. 228 \& Dusan Sidjanski, The Federal Future of Europe: From European Community to the European Union, USA: University of Michigan, 2000, hlm. 30.

50 Dalam Persidangan Menteri Luar Berikat di New York, Menteri Luar Berikat telah bersetuju tentang beberapa perkara iaitu; pertama menamatkan keadaan perang dengan Jerman; membantu Jerman Barat sekiranya berlaku sebarang serangan dari mana-mana pihak dan melihat serangan tersebut sebagai serangan ke atas mereka juga; membantu dalam mewujudkan pembentukan pasukan polis bergerak di peringkat daerah yang digunakan sekiranya berlaku darurat di Jerman Barat; penubuhan Menteri Luar Negara; menyemak semula Statut Pendudukan Berikat dan digantikan dengan perjanjian; dan menghapuskan atau melonggarkan kawalan Berikat ke atas industri penting Jerman Barat dan pembinaan kapal. Christopher Gehrz, 'Dean Acheson, the JCS and the "Single Package": American Policy on German Rearmament 1950', Diplomacy \& Statecraft, Jil. 12, No. 1, 2001, hlm. 136.

51 Francis H. Heller \& John R. Gillingham, NATO: The Founding of the Atlantic Alliance and the Integration of Europe, New York: Harry S. Truman Library Institute, 1992, hlm. 35-36 \& Michael G. Fry, Erik Goldstein dan Richard Langhorne, Guide to International Relations and Diplomacy, New York: Continuum, 2002, hlm. 78.

52 Beate Ruhm von Oppen (terj), Konrad Adenauer: Memoirs 1945-53, hlm. 295.

53 Stanley R. Sloan, NATO, The European Union, and the Atlantic Community: The Transatlantic Bargain Challenged, Maryland: Rowman \& Littlefield Publishers Inc., 2005, hlm. 21, Gunter Buchstab \& Reinhard Schreiner, Konrad Adenauer and the European Integration, Sankt Augustin: An Exhibition of the Archive for Christian Democratic Policy of the Konrad Adenauer Foundation, 2007, hlm. 12.

54 Der Spiegel, 02 Mac 2009.

55 Ronald Irving, Adenauer: Profiles in Power, hlm. 90 \& Angelina Topan, The European Integration Process: A Historical and Comparative Institutional Analysis, Berlin: Lit VERLAG Munster, 2001, hlm. 51. 
$56 \quad$ Ronald Irving, Adenauer: Profiles in Power, hlm. 135.

57 Michelle Cini, European Union Politics, Oxford: Oxford University Press, 2003., hlm. 23.

$58 \quad$ Ronald Irving, Adenauer: Profiles in Power, hlm. 136.

59 Arno Kappler, The Fact About Germany, Berlin: Vod Eppelheim, 1996,hlm. 29.

$60 \quad$ Ibid.

61 Konrad Adenauer, 'The Berlin Crisis: A Flagrant Violation of Human Rights', Vital Speeches of the Day, XXVII, September 1961, hlm. 706 an Hope M. Harrison, 'The Berlin Wall, Ostpolitik, and Détente', GHI Bulletin Supplement, 2003, hlm. 6.

62 Armin Grunbacher. 'Lecturer, The Chancellor's Forgotten Blunder: Konrad Adenauer's Foundation For Refugees and Expellees', German Politics, Jil. 13, No. 3, 2004, hlm. 144.

63 Ibid. 